УДК 378.1:004.77

JEL D83

DOI 10.31375/2226-1915-2021-2-108-120

ОСОБЛИВОСТІ ПІДГОТОВКИ МОРСЬКИХ ФАХІВЦІВ УКРАЇНИ

В УМОВАХ ПАНДЕМІЇ:

\section{РЕАЛІЇ ДИСТАНЦЙНОГО НАВЧАННЯ}

\section{I.M. Смирнова}

докт. пед. наук, професор Дунайський інститут

Начіонального університету

«Одеська морська академія» phd.smyrnova@gmail.com

Ю.В. Загородня канд. екон. наук, доцент

Азовський морський інститут

Національного університету

"Одеська морська академія

zagorodnia.uv@gmail.com

С.Б. Максимов

ст. викладач

Дунайський інститут

Начіонального університету

"Одеська морська академія»

maksimov15477@gmail.com

Анотація. Стаття присвячена актуальній проблемі сучасної освіти - дистанційному навчанню. Розглянуто питання впливу пандемії на підготовку спечіалістів морської галузі в Украӥні. У статті даються основні напрями розвитку дистаниійного навчання $i$ показуються відмінності дистаниійного навчання від традиційного. Розглянуто та проаналізовано особливості підготовки курсантів навчальних закладів морської галузі та виявлено позитивні та негативні сторони дистанчійного навчання для науково-педагогічних прачівників та здобувачів вищої освіти. Автори статті визначають необхідність підвищення якості підготовки морських фахівиів під час дистаниійноі освіти, через те, щуо людський фактор являється основною причиною аварійності суден та зниження безпеки мореплавства. Представлені результати дослідження розкривають проблемні аспекти організачї учбового процесу дистанційної форми навчання. Дослідження довели, щзо негативні сторони дистаниійної форми навчання суттево знижують якість підготовки спеціалістів морської галузі, щчо може привести до збільшення аварійності суден та зниження безпеки мореплавства. Запропоновано шляхи підвищення ефективності навчання при дистанційній формі навчання в умовах світовоі пандемії.

Ключові слова: дистанщійне навчання, якість освіти, заклади морської галузі, менеджмент морських ресурсів, аварійність суден, пандемія.

\section{(C) Смирнова I.М., Загородня Ю.В.,}

Максимов С.Б., 2021
УДК 378.1:004.77

JEL D83

DOI 10.31375/2226-1915-2021-2-108-120

ОСОБЕННОСТИ ПОДГОТОВКИ

МОРСКИХ СПЕЦИАЛИСТОВ УКРАИНЫ

В УСЛОВИЯХ ПАНДЕМИИ:

\section{РЕАЛИИ ДИСТАНЦИОННОГО ОБУЧЕНИЯ}

\section{И.М. Смирнова}

докт. пед. наук, профессор

Дунайский институт

Национального университета

"Одесская морская академия» phd.smyrnova@gmail.com

Ю.В. Загородняя

канд. экон. наук, доцент

Азовский морской институт

Наиионального университета

«Одесская морская академия» zagorodnia.uv@gmail.com

С.Б. Максимов

ст. преподаватель

Дунайский институт

Национального университета

"Одесская морская академия"

maksimov15477@gmail.com

Аннотация. Статья посвящена актуальнои проблеме современного образования - дистаниионному обучению. Рассмотрены вопросы влияния пандемии на подготовку спеииалистов морской отрасли в Украине. В статье рассмотрень основные направления развития дистаниионного обучения и показываются различия дистанционного обучения от традиционного. Рассмотрены и проанализированы особенности подготовки курсантов учебных заведений морской отрасли. Выявлены положительные и отричательные стороны дистаниионного обучения для научно-педагогических работников и соискателей высшего образования. Авторы статьи определяют необходимость повышения качества подготовки морских специалистов при дистаниионном образовании, так как человеческий фактор является основной причиной аварийности судов и снижения безопасности мореплавания. Представленные результаты исследования раскрывают проблемные аспекты организации учебного проиесса дистаниионной формы обучения. Исследования доказали, что отрицательные стороны дистанционной формы обучения существенно снижают качество подготовки спечиалистов морской отрасли, что может привести к увеличению аварийности судов и снижению безопасности мореплавания. Предложены пути повышения эффективности обучения при дистанционной форме обучения в условиях мировой пандемии.

Ключевые слова: дистанционное обучение, качество образования, учебные заведения морской отрасли, менеджмент морских ресурсов, аварийность судов, пандемия. 
UDC 378.1:004.77

\title{
JEL D83
}

DOI 10.31375/2226-1915-2021-2-108-120

\section{SPECIFICS OF TRAINING UKRAINIAN MARITIME SPECIALISTS IN A PANDEMIC: REALITIES OF DISTANCE LEARNING}

\author{
Iryna Smirnova \\ Doctor of Pedagogical Sciences, Professor \\ phd.smyrnova@gmail.com \\ ORCID: 0000-0003-2085-5391 \\ Danube Institute of the National University «Odesa Maritime Academy» \\ Yuliia Zahorodnia \\ $\mathrm{PhD}$ (Economics), Associate Professor \\ zagorodnia.uv@gmail.com \\ ORCID: 0000-0003-0320-540X \\ Azov Maritime Institute of the National University «Odessa Maritime academy» \\ Sergiy Maksymov \\ Senior Lecturer of the Engineering Department \\ maksimov15477@gmail.com \\ ORCID: 0000-0002-2290-5439 \\ Danube Institute of the National University «Odesa Maritime Academy»
}

Abstract. Modern higher education institutions faced a huge problem during the global pandemic. The topical issue was the provision of quality educational services to higher education seekers in a pandemic around the world. Many countries in 2020 have decided to use distance learning as the only way to continue the educational process without interrupting it indefinitely. Distance learning today is one of the most effective and promising training systems. The emergence and active spread of distance learning is an adequate response of the education systems of many countries to the processes of integration taking place in the world, the movement towards the information society.

Purpose. The purpose of this article is to systematize various aspects of distance education in institutions of the maritime sector of Ukraine in a global pandemic and to find solutions to issues that arise during the development of distance education and training of maritime professionals; identification of positive and negative aspects of the introduction of distance learning.

Methods. To solve the problem, the following methods were used: the method of theoretical generalization, the method of analysis and synthesis, the method of systematization, the method of deduction.

Results. The analysis of the results of distance learning in maritime institutions was carried out and its strengths and weaknesses were identified. The ways of improving the quality of distance education are analyzed. Further ways of development and improvement of distance learning are proposed.

Originality. The basis of the educational process in distance learning is the controlled, intensive and purposeful independent work of a student who can study in a place convenient for himself, according to an individual schedule. In accordance with this, the educational process should be organized in such a way as to ensure the student's independent mastering of the educational material, the implementation and timely delivery of individual assignments.

Output. The main problem of training applicants for higher education in the maritime sector of Ukraine in a pandemic in distance education is the lack of opportunity for cadets to gain practical skills in working with ship equipment that exists in educational institutions. This negatively affects the quality of learning by cadets. In the future, this may lead to increased ship accidents and reduced maritime safety. It is necessary to develop interaction between educational institutions; make full use of technological opportunities; determine the goals and prospects for the development of distance learning, etc.

Keywords: distance learning, quality of education, maritime institute, management of marine resources, ship accident rate, pandemic. 
DEVELOPMENT OF MANAGEMENT

AND ENTREPRENEURSHIP METHODS ON TRANSPORT, № 2 (75), 2021
РОЗВИТОК МЕТОДІВ

УПРАВЛІННЯ ТА ГОСПОДАРЮВАННЯ

НА ТРАНСПОРТІ, № 2 (75), 2021
Постановка проблеми. Сучасні заклади вищої освіти зіткнулися 3 величезною проблемою організації освітнього процесу в період світової пандемії. Актуальним питанням стало надання якісних освітніх послуг здобувачам вищої освіти в умовах пандемії у всьому світі. Більш ніж 50 країн світу в 2020 році прийняли рішення про використання дистанційної форми навчання як єдину можливість продовжити освітній процес без його переривання на невизначений термін [1]. Дистанційне навчання сьогодні є однією 3 найбільш ефективних i перспективних систем підготовки фахівців. Поява та активне розповсюдження віддалених форм навчання $\epsilon$ адекватною та своєчасною реакцією систем освіти багатьох країн на процеси світової інтеграції та руху до інформаційного суспільства.

Дистанційне навчання вперше з'явилося ще в 1951 році в Австралії. У зв'язку з величезною відстанню до найближчих шкіл і відсутністю можливості учнів добиратися на навчання було створено School of the Air («Школа по радіо»), яка фактично являлася різновидом заочного навчання. В кінці 1980 років у Сполучених Штатах Америки в Національному технологічному університеті (National Technological University) так само почала застосовуватися система дистанційної освіти. Більш того, вже в 1987 році в Америці була створена Американська асоціація дистанційної освіти (United States Distance Learning Association). Суттєвою відмінністю американської дистанційної освіти від сучасної було те, що раніше така освіта використовувалася спеціально для людей 3 обмеженими фізичними можливостями, а зараз у зв'язку зі світовою пандемією практично всі навчальні заклади світу перейшли на таку форму освітнього процесу [2].

Спеціальності, які не вимагають проведення практичних занять у лабораторіях, на спеціалізованих тренажерах в меншій мірі зіткнулися 3 проблемами, викликаними переходом на дистанційну форму навчання. Більшість закладів морської галузі опинилися в нестандартній ситуації, тому що підготовка здобувачів вищої освіти (курсантів) вимагає проведення занять в спеціалізованих аудиторіях, лабораторіях 3 використанням професійних технічних засобів та тренажерів.

Огляд останніх досліджень та літератури. Питання дистанційної освіти в період світової пандемії наразі $є$ досить актуальним та досліджується багатьма вітчизняними та зарубіжними спеціалістами $[3 ; 5-10 ; 12$; 14]. Практичний досвід показав необхідність подальшого дослідження 3 метою підвищення якості надання освітніх послуг у закладах морської галузі та мінімізації негативних сторін такої форми навчання. Зокрема, кафедра менеджменту Львівського торговельно-економічного університету стверджує, що «децентралізація навчання дозволяє уникнути переміщення персоналу в центр навчання і тим самим отримати виграш у часі, економію витрат на транспорт і відволікання персоналу від роботи» [3].

Задачі дослідження. Метою даної статті є спроба систематизувати різні аспекти питання дистанційної освіти в закладах морської галузі України в умовах світової пандемії та розглянути варіанти рішень 3 ряду 
питань, що виникають у ході розвитку систем дистанційної освіти та підготовки фахівців морської галузі; виявити позитивні та негативні сторони впровадження дистанційної форми навчання.

Основний матеріал дослідження. Основною причиною аварійності суден за даними міжнародних організацій, в більшості випадків, $\epsilon$ людський фактор. В першу чергу, аварії виникають внаслідок помилок командного складу і портових працівників, задіяних в організації руху суден, а саме лоцманів, буксирів, служб регулювання руху суден тощо.
Клуб взаємного страхування P \& I Club фіксує близько 73 \% аварій через людський фактор, а саме через помилки екіпажу судна. Основними причинами виникнення аварійних ситуацій відповідно до розслідувань, EMSA $є$ : помилкові дії екіпажу (людський фактор) (67\%), технічні помилки обладнання (24\%), небезпечні речовини (4\%), погодні умови (3\%), третя сторона (3\%) (рисунок 1$)[4 ; 5]$. Тому підготовка фахівців морської галузі на високому рівні дуже важлива для забезпечення безпеки мореплавання.

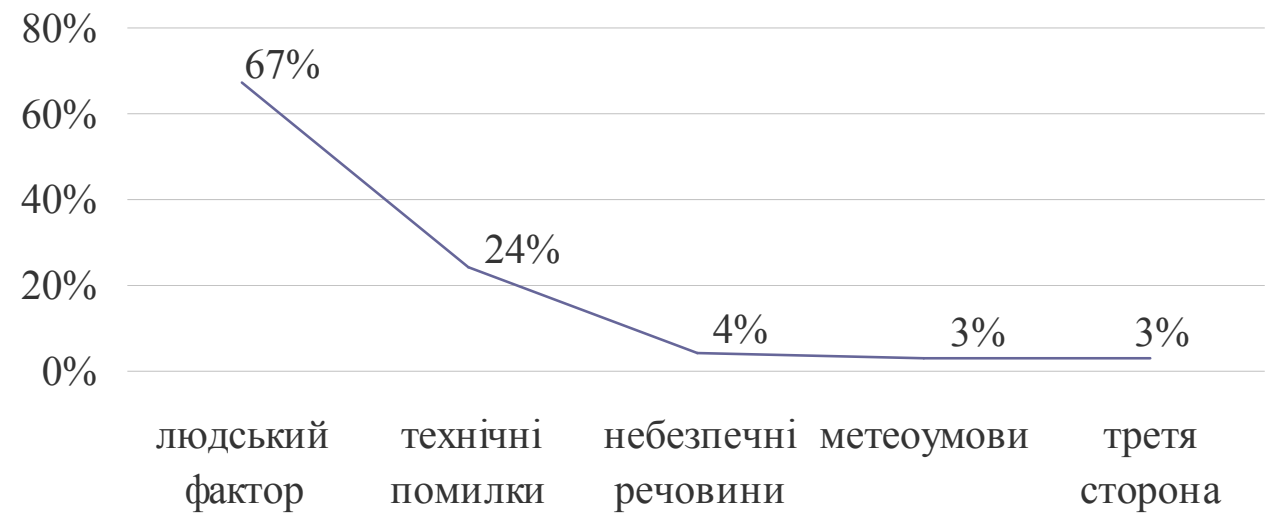

Рис. 1. Причини аварійності суден за даними EMSA в період 2014-2020 pp.

Джерело: розроблено авторами на основі аналізу [3].

Україна та багато інших країн дистанційну форми навчання до 2020 року майже не застосовували через недостатній розвиток технічних засобів нових інформаційних та телекомунікаційних технологій. Перешкодою для широкого впровадження систем дистанційної освіти є відсутність розроблених методів організації дистан- ційної освіти, включаючи структурні, методичні та організаційні рішення. Актуальність використання дистанційного навчання очевидна для всіх країн світу. Наприклад, за даними Департаменту Освіти США лише $43 \%$ студентів вищих навчальних закладів цієї країни молодше 25 років років, чверть - молодь 18-22 років; 
DEVELOPMENT OF MANAGEMENT

AND ENTREPRENEURSHIP METHODS ON TRANSPORT, № 2 (75), 2021
РОЗВИТОК МЕТОДІВ

УПРАВЛІННЯ ТА ГОСПОДАРЮВАННЯ

НА ТРАНСПОРТІ, № 2 (75), 2021 інша частина студентів - дорослі люди, обтяжені сім'єю та роботою. Внутрішні форми університетської освіти для них досить проблематичні [6].

Для забезпечення раціонального освітнього процесу в умовах світової пандемії закладами вищої освіти було прийнято рішення про використання спеціалізованої інфраструктури i цифрових сервісів, які активно використовуються в усьому світі. Якість навчання можна визначити як задоволення вимог замовника, а саме відповідність знань i умінь випускників навчального закладу вимогам, що пред'являються 3 боку ринку праці. Суспільство через попит на випускників на ринку праці доводить до закладів вищої освіти свої потреби і контролює рівень підготовки фахівців.

3 точки зору підходів до оцінки i контролю якості існують дві моделі управління якістю. Перша модель заснована на безпосередньому контролі знань здобувачів. Друга модель управління якістю освіти заснована на контролі не тільки знань учнів, а й процесів навчання, їх організації та застосовуваних засобів. Згідно 3 реаліями інформатизації освіти їі якість характеризується наступними групами показників: показники якості змісту освіти; показники якості технологій навчання; показники якості результатів освіти [7; 8].

Фахівці ЮНЕСКО в 2020 році представили актуальну класифікацію інструментів, що дозволяють здійснювати дистанційне навчання, а саме [9]:
- ресурси, що забезпечують психосоціальну підтримку учасників освітніх відносин в умовах пандемії;

- систему адміністрування цифрових навчанням (Google class-room, Moodle, Blackboard, Canvas);

- додатки для навчання на базі мобільних пристроїв;

- програми з розширеною оффлайн-функціональністю;

- масові відкриті онлайн-курси;

- сервіси самонавчання;

- електронні рідери;

- програми, що забезпечують можливість спільної роботи в режимі онлайн (Skype, Zoom, GoogleMeet, Micrisift Teams);

- інструменти для створення цифрового навчального контенту i численні електронні бази навчальних матеріалів.

Всі країни світу зіткнулися 3 певними труднощами при організації навчального процесу дистанційного навчання. У більшості навчальних закладів раніше не було схожого досвіду і виникла необхідність повністю змінити звичайну форму навчального процесу.

У результаті дослідження авторами було виявлено деякі негативні сторони підготовки курсантів в закладах морської галузі України при дистанційній формі навчання.

Основною проблемою дистанційної освіти є відсутність якісного методичного забезпечення. Однак ряд дослідники виділяють його організаційні та технічні проблеми: розробка єдиного стандарту зберігання навчальних інформаційних ресурсів; забезпечення ефективності спілкування викладачів та студентів; створення засобів дистанційного управління 
DEVELOPMENT OF MANAGEMENT

AND ENTREPRENEURSHIP METHODS ON TRANSPORT, № 2 (75), 2021
РОЗВИТОК МЕТОДІВ

УПРАВЛІННЯ ТА ГОСПОДАРЮВАННЯ

НА ТРАНСПОРТІ, № 2 (75), 2021 навчальним процесом; розробка ефективного планування освітнього процесу; ефективне подання навчального матеріалу; забезпечення співпраці студентів; забезпечення дистанційного доступу до інформаційних ресурсів [10].

Особливістю підготовки курсантів закладів морської галузі України $€$ використання різних сучасних тренажерів, що дозволяють курсантам отримати практичні навички роботи, які $\epsilon$ максимально наближеними до реальних умов управління і експлуатації судна, а саме симулятори містка і машинного відділення. Під час дистанційної освіти стає недоступним використання в навчальному процесі спеціалізованого навчального обладнання, що негативно позначається на рівні підготовки курсантів, істотно знижуючи їх практичні знання i навички у використанні суднового устаткування, що в подальшому може призвести до негативних наслідків в процесі експлуатації судна. На сьогоднішній день провідними закладами морської галузі України в процесі підготовки фахівців застосовується наступне матеріально-технічне забезпечення освітньої діяльності [11]:

- повномасштабні тренажери машинного відділення, включаючи аварійну дизельгенераторну панель, центральний пост управління, машинне відділення 3 мнемосхемою управління, оснащені дистанційним терміналом управління, а також пульт управління інструктора;

- спеціалізовані стенди для дослідження, настройки і технічного обслуговування регуляторів швидкості;
- спеціалізовані стенди призначені для діагностики роботи електрогідравлічних рульових машин, аналізу використання електроенергії;

- рульові машини;

- лабораторні холодильні установки системи кондиціонування повітря;

- навігаційні тренажери, які включають навігаційні містки і персональні комп'ютери із спеціалізованим програмним забезпеченням i засобами візуалізаціі;

- повномасштабні містки 3 візуалізацією, які забезпечені спеціальним обладнанням для відображення електронних карт ECDIS;

- персональні комп'ютери із спеціалізованим програмним забезпеченням для вивчення методик проведення розрахунків за техніко-економічним обгрунтуванням вдосконалення і модернізації суднового устаткування.

Більшість матеріально-технічного забезпечення освітньої діяльності є основою практичної підготовки спеціалістів морської галузі. Його неможливо використовувати в умовах дистанційного навчання, необхідна фактична присутність здобувачів вищої освіти в спеціалізованих навчальних аудиторіях. Теоретичну частину навчальних дисциплін можна вивчати дистанційно і це матиме мінімальний вплив на якість засвоюваного матеріалу курсантами, але 3 практичними заняттями це стає важко, а часом просто неможливо. Тобто, можна зробити висновок, що не всі дисципліни можливо досконально вивчити в дистанційному форматі навчання, зберігаючи якість 
DEVELOPMENT OF MANAGEMENT

AND ENTREPRENEURSHIP METHODS ON TRANSPORT, № 2 (75), 2021
РОЗВИТОК МЕТОДІВ

УПРАВЛІННЯ ТА ГОСПОДАРЮВАННЯ

НА ТРАНСПОРТІ, № 2 (75), 2021 отриманих знань курсантами/студентами.

Всі курсанти/студенти закладів морської галузі України протягом навчання зобов'язані проходити плавальну практику. У період пандемії вони зіткнулися 3 обмеженнями переміщення по всьому світу, що для них прирівнюється до невиконання навчальних планів, а саме до браку плавального цензу для отримання навчальних i робочих документів моряка. Наприклад, за 4 роки навчання курсанти денної форми підготовки повинні набрати мінімум 12 місяців плавпрактики, для отримання робочого диплома офіцера. Але у зв'язку з закриттям кордонів багатьох країн курсанти не мають можливості своєчасно потрапити на борт судна для проходження практики, а також в подальшому вчасно списатися з судна i повернутися 3 рейсу, без негативного впливу для навчального процесу, що, в свою чергу, призводить до необхідності оформлення повторного навчання, а також збільшення часу i фінансових витрат для здобуття вищої освіти.

Дистанційне навчання істотно знижує якість отриманих знань курсантами, так як перебуваючи вдома перед моніторами комп'ютерів і інших сучасних гаджетів існує можливість використання в період контрольних заходів сторонніх джерел інформації, що неможливо контролювати 3 боку викладача. Тим самим, оцінка знань курсантів не може бути повною мірою об'єктивною оскільки не можна виключити фактор списування з боку здобувачів вищої освіти. Результат опитування курсантів 4-го курсу денної форми навчання в Азов- ському морському інституті НУ «ОМА» показав, що $81 \%$ опитаних курсантів вважають дистанційну форму навчання менш ефективною ніж звичайний формат проведення занять.

Одним 3 невід'ємних складових традиційного навчання $\epsilon$ особисте спілкування курсантів. Взаємодія курсантів 3 викладачами, між собою, обмін досвідом у практичній роботі, неформальне спілкування допомагають розширити кругозір, знайомства i навчити курсантів вмінню домовлятися, шукати компроміси, знаходити виходи зі складних ситуацій тощо. У період пандемії, в умовах обмеженого пересування і соціальної самоізоляції такої можливості у них немає. Наприклад, Білл Гейтс здобував освіту в Гарварді і зустрів Стіва Балмера, що в подальшому призвело до створення компаніï Microsoft [12].

Дистанційне навчання позбавляє курсантів процесу конспектування, що, в свою чергу, тренує швидкість письма, при цьому впливає на формування і розвиток пам'яті, допомагає навчитися оперативно переробляти безперервний потік інформації та фіксувати найбільш важливу. Всі ці навички дуже корисні в повсякденному житті, але дистанційне навчання їх унеможливлює [13].

Ще однією проблемою в отриманні дистанційної освіти в період пандемії є недосконалість технічного оснащення. Не всі здобувачі вищої освіти мають постійний доступ до сучасного обладнання та високошвидкісного інтернету, які створюють безперешкодний доступ до знань. Існує залежність можливості курсантів виходити на зв'язок 3 викладачами та зовнішніми факторами, що не доз- 
DEVELOPMENT OF MANAGEMENT

AND ENTREPRENEURSHIP METHODS ON TRANSPORT, № 2 (75), 2021
РОЗВИТОК МЕТОДІВ

УПРАВЛІННЯ ТА ГОСПОДАРЮВАННЯ

НА ТРАНСПОРТІ, № 2 (75), 2021 воляють це зробити. Наприклад, раптове відключення електрики призведе до пропуску онлайн заняття [14].

Необхідний елемент отримання якісної освіти є контроль за знаннями курсантів 3 боку викладача. Відсутність контролю створює у курсантів відчуття додаткової свободи, хоча при дистанційній формі навчання необхідно навпаки посилювати власну мотивацію і самоменеджмент для досягнення поставлених результатів навчання. Весь контроль навчання лягає на самосвідомість курсантів, їх самоорганізованість і дисциплінованість. Домашня обстановка часто не дозволяє повноцінно отримувати інформаційний потік 3 максимальною віддачою, так як сторонні чинники часто відволікають курсантів від освітнього процесу і негативно впливають на отримання інформаціі.

Основною ідеєю методики дистанційного навчання $є$ створення освітнього інформаційного середовища, включаючи комп'ютерні джерела інформації, електронні бібліотеки, відео- та аудіоколекції, книги та посібники. Компонентом такого освітнього середовища $\epsilon$ як слухачі, так i викладачі, взаємодія яких здійснюється через засоби сучасного телекомунікаційного зв'язку. Таке освітнє середовище надає слухачам унікальні можливості для здобуття знань як самостійно, так і під керівництвом викладачів (рисунок 2).

Незважаючи на багато негативних моментів підготовки здобувачів вищої освіти при дистанційній формі навчання, які відзначають як вони самі, так і науково-педагогічні працівники закладів освіти, можна відзначити і позитивні сторони даного виду освітнього процесу.

По-перше, освіта стала доступною практично кожному курсанту. Це $\epsilon$ головною перевагою дистанційної освіти для закладів морської галузі України. Перебуваючи в рейсах, курсанти в основному мали доступ до лекційних матеріалів тільки в текстових форматах, що призводило до істотного нерозуміння навчального матеріалу, при цьому не було можливості отримати консультацію викладача онлайн. Сьогодні ця проблема вирішилася завдяки використанню освітніх платформ, за допомогою яких курсанти в режимі онлайн спілкуються 3 викладачами 3 будь-якої точки світу. В даний час, перебуваючи в рейсі, можна бути присутнім на заняттях особисто і не відставати від навчальної програми. Це призводить до суттєвого зниження навантажень на курсантів, які повертаються 3 рейсу і стрімко адаптуються до навчального процесу. Онлайн заняття в закладах морської галузі України найчастіше представлені в двох формаTax:

- прямий ефір;

- заздалегідь записане заняття, до якого є доступ курсантів.

Такий вид занять багато в чому повторює звичні заняття, при яких відбувається спілкування курсантів між собою, а також з викладачем.

По-друге, дистанційне навчання розвиває самостійність в освоєнні курсантами навчального матеріалу, що розширює можливості в розподілі часу в цілому. Ця форма освіти добре поєднується 3 роботою в період навчання. 


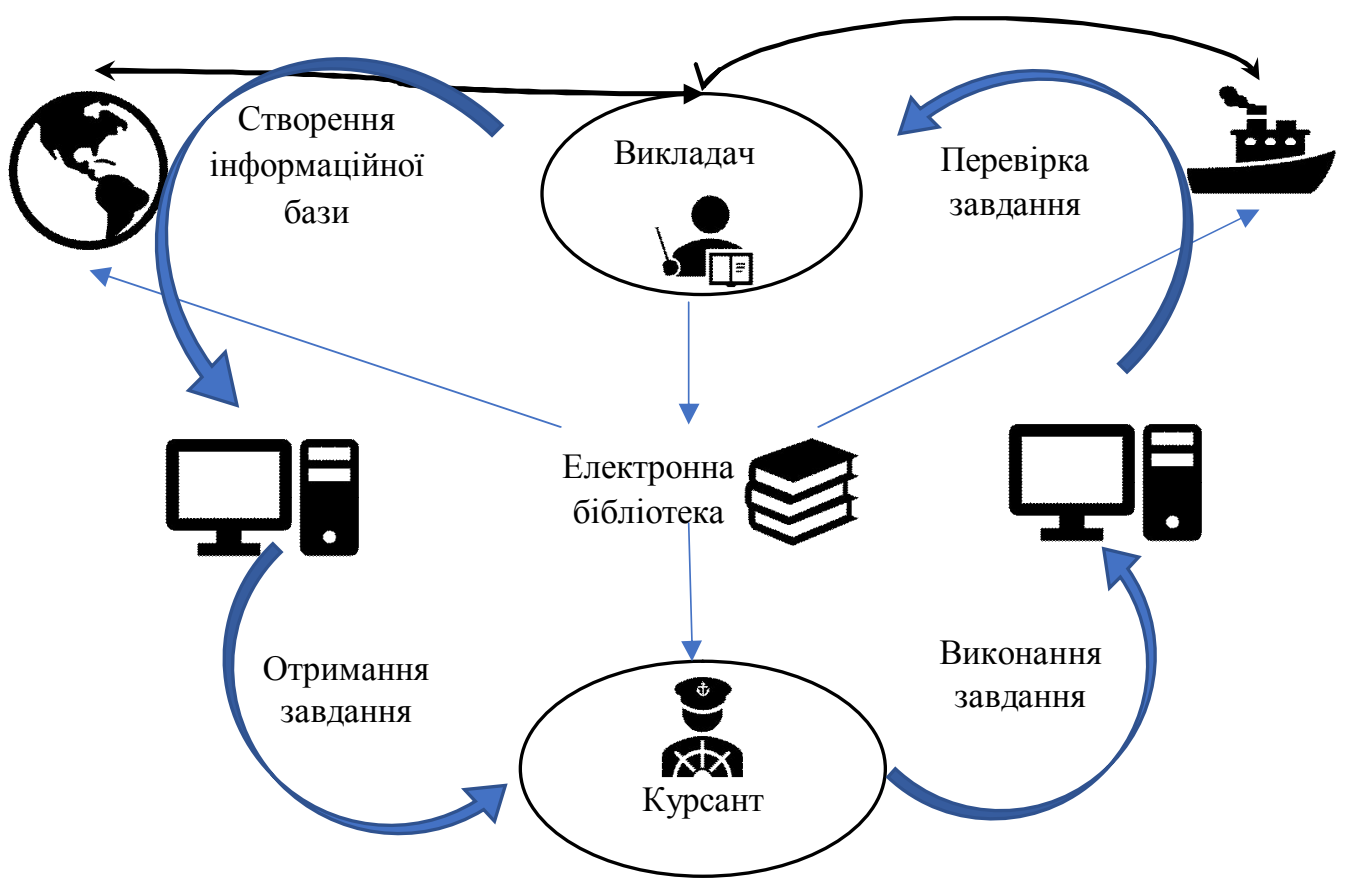

Рис. 2. Сучасне освітньо-інформачійне середовище при дистаниійній формі навчання

Джерело: розроблено авторами

По-третє, дистанційна освіта позитивно позначається на зниженні витрат як навчальних закладів, так i курсантів. Навчальні заклади, що надають послуги навчання, отримали можливість суттєво знизити витрати від оренди приміщень, закупівлі меблів і устаткування. Курсанти, в свою чергу, не залежать від транспорту (а в період пандемії, актуальність цього питання зросла в зв'язку 3 введеними обмеженнями по переміщенню населення навіть в межах міста) і не несуть додаткові транспортні витрати для відвідування нав- чального закладу, при цьому зберігаючи особистий вільний час.

Повноцінна підготовка курсантів неможлива без постійного вдосконалення знань викладацького складу. Сьогодні істотно знизилася вартість онлайн-курсів підвищення кваліфікації педагогічного складу, участі в конференціях, семінарах тощо. З'явилася можливість брати участь у міжнародних заходах, не виходячи $з$ дому, при цьому можливо максимально знизити витрати на транспортні витрати, проживання в готелі та інші витрати, пов'язані з поїздкою за кордон, що дає можливість як викладачам, так i 
DEVELOPMENT OF MANAGEMENT

AND ENTREPRENEURSHIP METHODS ON TRANSPORT, № 2 (75), 2021
РОЗВИТОК МЕТОДІВ

УПРАВЛІННЯ ТА ГОСПОДАРЮВАННЯ

НА ТРАНСПОРТІ, № 2 (75), 2021 курсантам підвищити свої знання та кваліфікаційний рівень по навчальним дисциплінам.

Дистанційна освіта може бути ефективна для наступних категорій слухачів: найбільш здібних студентів, які вже мають необхідні знання та бажання закінчити освітню програму за короткий час; слухачі, які хочуть поєднати навчання 3 підприємницькою діяльністю; слухачі, які бажають виконати спеціальні освітні програми, що складаються 3 курсів, забезпечуються різними навчальними закладами, в тому числі навчальними закладами різних країн; слухачі які були географічно відокремлені від освітніх ресурсів, необхідних їм; осіб, які не здобули освіту в молодому віці; особи, які готуються до вступу в навчальний заклад; особи, які прагнуть знайти можливість заповнити прогалини на окремих курсах; мобільні студенти; іноземні працівники, сім'ї військових або постійно мігруючих; слухачі, які мають фізичні, фізіологічні чи емоційні проблеми; студенти, які займаються мистецтвом, займаються спортом і не хочуть переривати освіту.

Стратегію розвитку дистанційної освіти можливо розвивати наступним чином:

- розвивати взаємодію між навчальними закладами;

- розробляти організацію та управління розвитком дистанційної освіти для більш гнучкого використання технологічних можливостей згідно потреб конкретних програм;

- визначати цілі та перспективи дистанційного навчання;

- розробляти сучасні моделі взаємодії, відображення потенційних відносин між навчальними закладами регіону та інших країн

Висновки. Таким чином, дистанційне навчання - це нова прогресивна форма організації навчального процесу, заснована на принципі самостійного навчання здобувачів освіти за допомогою розроблених інформаційних ресурсів, характерною рисою якої $є$ віддалення студента від викладача у просторі та часі, з урахуванням можливості у будь-який час підтримати діалог за допомогою технічних комунікацій. Система дистанційного навчання являється економічною як для держави, навчальних закладів та здобувачів освіти через наступні основні фактори:

- відсутність «стін» у навчальних закладах знижують комунальні витрати;

- витрати на переїзд до місця навчання та проживання відсутні або значно скорочені;

- можливість поєднати виробничу діяльність та навчання без переривання виробничої діяльності.

Основною особливістю підготовки здобувачів вищої освіти в закладах морської галузі України в умовах пандемії при дистанційній формі освіти є відсутність можливості курсантів отримати практичні навички роботи 3 судновим обладнанням, представленим в навчальних закладах, що негативно позначається на якості засвоєння практичного матеріалу і надалі може привести до підвищення аварійності суден i зниження безпеки мореплавання. Одним 3 можливих заходів подолання даної проблемної ситуації може бути поділ навчальної групи на підгрупи 3 меншою кількістю людей 3 викорис- 
танням повного комплексу карантинних заходів.

Раціональним заходом у подоланні впливу дистанційного навчання на підготовку морських фахівців також $є$ збільшення кількості прак- тичних робіт шляхом впровадження в навчальний процес факультативних занять 3 дисциплін, що вимагає практичного відпрацювання на тренажеpax, в післякарантинний період.

\section{ЛІТЕРАТУРА}

1. Bullen, M. 'Distance Education \& Technology Continuing Studies' 1996.

2. Дистанционное обучение в разных странах мира: опыт онлайнобразования // ФОКСФОРД. URL: https:// https://externat.foxford.ru/ polezno-znat/e-education

3. Міжнародний досвід дистаниійного навчання // Кафедра менеджменту Львівського торговельно-економічного університету. URL: https:// kerivnyk. info/mizhnarodnyj-dosvid-dystantsijnoho-navchannya

4. Annual Overview of Marine Casualties and Incidents // EMSA. URL: http://www.emsa.europa.eu/tags/85-annual-overview.html

5. Мальцеев А.С. Теория и практика безопасного управления судном при маневрировании: дис. докт. техн. наук: 05.22.16. Одеса, 2007. 395 с.

6. Secretary Antony J. Blinken Remarks to the Press on the COVID Response // U.S. Department of State. URL: https://www.state.gov

7. Safi ullin Lenar et al. / Procedia - Social and Behavioral Sciences 131 ( 2014 ). 111-117.

8. Li, P. (2013) Effect of Distance Education on Reference and Instructional Services in Academic Libraries // Internet Reference Services Quarterly 18 (1), рр. 77-96.

9. Решения для дистанциионного обучения // UNESCO. URL: https:// en. unesco.org/covid19/educationresponse/solutions

10. Panasyuk M.V., Pudovik E.M., Sabirova M.E.. (2013) Optimization of regional passenger bus traffic network // Procedia Economic and finance. Volume 5, pp. 589-596.

11. Відомості про кількісні та якісні показники матеріально-технічного забезпечення освітньої діяльності у сфері вищої освіти // ONMA. URL: http://www.onma.edu.ua/wp-content/uploads/2016/10/Materialno-tehnichnividomosti_popravky-2018.pdf

12. Билл Гейтс и Стив Балмер: магнаты Microsoft // Habr. URL: https:// habr.com/ru/sandbox/73190

13. Плюсы и минусы дистанциионного обучения // Accel URL: https://theaccel.ru/plyusy-i-minusy-distancionnogo-obucheniya 
14. Challenges Students Face with Online Learning and How to Overcome Them // MERATAS. URL: https://www.meratas.com/blog/5-challenges-students-facewith-remote-learning

\section{REFERENCES}

1. Bullen, M. (1996). 'Distance Education \& Technology Continuing Studies'.

2. Distancionnoe obuchenie $v$ raznyh stranah mira: opyt onlajn-obrazovaniya [Distance learning in different countries of the world: the experience of online education]. FOKSFORD. Retrieved from: https:// https://externat. foxford.ru/polezno-znat/e-education [in Russian].

3. Mizhnarodnij dosvid distancijnogo navchannya [International experience of distance learning]. Kafedra menedzhmentu L'vivs'kogo torgovel'no-ekonomichnogo universitetu. Retrieved from: https:// kerivnyk.info/mizhnarodnyjdosvid-dystantsijnoho-navchannya [in Ukrainian].

4. Annual Overview of Marine Casualties and Incidents // EMSA. URL: http://www.emsa.europa.eu/tags/85-annual-overview.html

5. Mal'cev, A. S. (2007). Teoriya i praktika bezopasnogo upravleniya sudnom pri manevrirovanii [Theory and practice of safe control of the vessel during maneuvering]: dis. dokt. tekhn. nauk: 05.22.16. Odesa, 395 [in Russian].

6. Secretary Antony J. Blinken Remarks to the Press on the COVID Response // U.S. Department of State. Retrieved from: https://www.state.gov

7. Safi ullin Lenar et al. Procedia - Social and Behavioral Sciences 131 (2014). 111-117.

8. Li, P. (2013). Effect of Distance Education on Reference and Instructional Services in Academic Libraries. Internet Reference Services Quarterly 18 (1), pp. 77-96.

9. Resheniya dlya distancionnogo obucheniya [Solutions for distance learning]. UNESCO. Retrieved from: https://en.unesco.org/covid19/ educationresponse/ solutions [in Russian].

10. Panasyuk, M.V., Pudovik, E.M. \& Sabirova, M.E. (2013). Optimization of regional passenger bus traffic network // Procedia Economic and finance. Volume 5, pp. 589-596.

11. Vidomosti pro kil'kisni ta yakisni pokazniki material'no-tekhnichnogo zabezpechennya osvitn'oï diyal'nosti u sferi vishchoï osviti [Information on quantitative and qualitative indicators of material and technical support of educational activities in the field of higher education]. ONMA. Retrieved from: http://www.onma.edu.ua/wp-content/uploads/2016/10/Materialno-tehnichni-vidomosti popravky-2018.pdf [in Ukrainian].

12. Bill Gejts \& Stiv Balmer: magnaty Microsoft. Habr. Retrieved from: https://habr.com/ru/sandbox/73190/ [in Russian]. 
13. Plyusy i minusy distancionnogo obucheniya [Pros and cons of distance learning]. Accel. Retrieved from: https://the-accel.ru/plyusy-i-minusy-distancionnogo-obucheniyal [in Russian].

14. Challenges Students Face with Online Learning and How to Overcome Them. MERATAS. Retrieved from: https://www.meratas.com/blog/5-challengesstudents-face-with-remote-learning

Стаття надійшла 02.06.2021

Посилання на статтю: Смирнова І. М., Загородня Ю. В., Максимов С.Б. Особливості підготовки морських фахівців України в умовах пандемії: реалії дистанційного навчання // Розвиток методів управління та господарювання на транспорті: Зб. наук. праць, 2021. № 2 (75). C. 108-120. DOI 10.31375/2226-1915-2021-2-108-120.

Article received 02.06.2021

Reference a JournalArtic: Smirnova, Iryna, Zahorodnia, Yuliia \& Maksymov Sergiy. (2021). Peculiarities of marine specialists training in Ukraine in the conditions of the pandemic: realities of remote education. Development of management and entrepreneurship methods on transport. 2 (75), 108-120. DOI 10.31375/2226-1915-20212-108-120. 